Mitteilungen der Österreichischen Geographischen Gesellschaft, 162. Jg., S. 65-90

(Annals of the Austrian Geographical Society, Vol. 162, pp. 65-90)

Wien (Vienna) 2020, https://doi.org/10.1553/moegg162s65

\title{
Busting the Scales: From Small-Scale Informal TO InVESTOR-Driven Urban DeVELOPMENTS. The Case of Tirana / Albania
}

\author{
Daniel GÖLER, Bamberg, and Dimitër DOKA, Tirana [Tiranë]* \\ Initial submission / erste Einreichung: 05/2020; revised submission / revidierte Fassung: 08/2020; \\ final acceptance / endgültige Annahme: 11/2020 \\ with 6 figures and 1 table in the text
}

\section{CONTENTS}

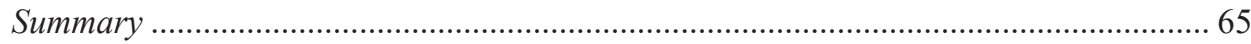

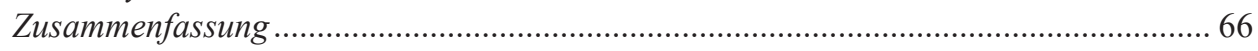

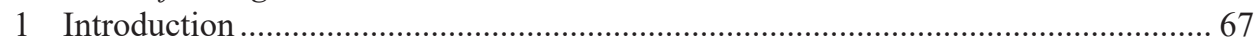

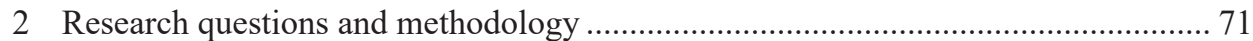

3 Conceptual focus on Tirana: Moving towards an evolutionary approach................. 72

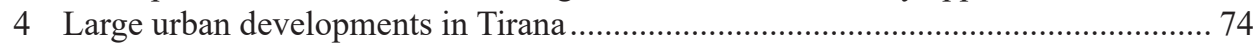

5 Discussion and problematisation........................................................................ 84

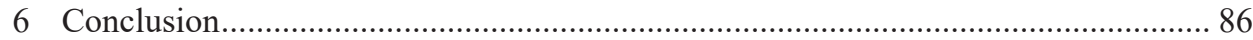

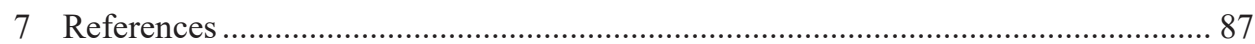

\section{Summary}

Tirana, the Albanian capital, started its urban transition processes after the fall of communism in a rather small-scale and mostly informal manner. Three decades later, urban development in the metropolis with its tripled population has generally formalised. The built fabric experienced a metamorphosis into a globalised urban structure. During the last years, a certain number of megaprojects (in Albanian terms) arose in the city, such as mixed-use skyscrapers, high-rise apartment buildings and big shopping malls or other commercial buildings. In this context, three topics seem to be of urban geographic interest.

The first is the overwhelming scalar dimension of the projects as well as the randomness of function and design. Tirana's skyline shows more and more elements of globalised

\footnotetext{
* Prof. Dr. Daniel GöLer, Institute of Geography, Geographic Migration and Transition Studies, University of Bamberg, D-96045 Bamberg, Germany, ORCID iD: 0000-0003-0377-0724; Prof. Dr. Dhimitër DoKA, Department of Geography, Faculty for History and Philology, University of Tirana, Tirana [Tiranë], Albania. Emails: daniel.goeler@uni-bamberg.de; dhdoka@yahoo.com.
} 
structures, but from an organisational point of view there is no corresponding functional internationalisation, for example, via the global financial market. In fact, quite the opposite is true: both the investors and the capital are mainly of Albanian origin. In such contexts, the powerful role and position of national elites, the second topic, may not come as a surprise. The key players seem to be very close to politics; sometimes political representatives are actively involved. Overall, there is no transparency in decision-making. Finally, it is highly problematic that some of the large urban developments are organised as public-private partnerships. In such cases, the public sector provides the property, applies for approval and then transfers the responsibility to private developers. This model fosters urban development and renewal, but at the same time, the profits will be privatised. All in all, we note in Tirana - and with a grain of salt this is true for the ex-socialist period as a whole - an urbanism of exception that can only be partially explained with common theoretical approaches, but rather requires an appropriate consideration of the evolutionary background, thus a relational perspective. We take up the concept of the "ordinary city" and discuss the scope of socialism and post-socialism as explanatory concepts.

Keywords: Urban growth, urbanisation, large urban developments, transition, post-socialist urbanism, Albania, Tirana

\section{Zusammenfassung}

\section{GeSPRENGTE MASSSTÄBLICHKEIT: VON DER KLEINTEILIGEN INFORMELLEN ZUR INVESTOREN-GeSTEUerten StADTENTWiCKLung. Das BeisPiel Tirana, AlbaniEn}

Informalität und Kleinteiligkeit sind wesentliche Kennzeichen der Transformationsprozesse der albanischen Hauptstadt Tirana nach dem Ende des Kommunismus. Drei Jahrzehnte später hat sich die Stadtentwicklung der stark wachsenden Metropole sukzessive formalisiert und die Physiognomie an globalisierte Strukturen angenähert. In den letzten Jahren wurde eine Reihe städtebaulicher Großprojekte wie Hochhäuser mit Funktionsmischung, reine Appartementkomplexe oder Shopping Malls errichtet. Weitere befinden sich im Stadium der Planung oder Realisierung. Drei Themenfelder erscheinen in diesem Zusammenhang von stadtgeographischem Interesse.

Das ist zunächst vor allem die Maßstäblichkeit der Projekte sowie die Beliebigkeit von Funktion und Gestalt. Tiranas Skyline trägt mehr und mehr Elemente eines globalisierten Urbanismus. In organisationaler Hinsicht korrespondiert diese Entwicklung nicht mit einer entsprechenden Internationalisierung über den Kapitalmarkt, ganz im Gegenteil: Sowohl die Investoren als auch das Kapital sind weitgehend albanischen Ursprungs. Weniger überraschend ist dann die ausgeprägte Machtposition der Eliten. Die maßgeblichen Akteure pflegen Nähe zur Regierungspolitik; bisweilen ist letztere direkt in die Investments involviert. Entscheidungsprozesse sind wenig transparent. Hochproblematisch ist die Organisation einiger der Großprojekte als Public-Private-Partnership. In solchen Fällen stellt die öffentliche Hand den Grund zur Verfügung, sorgt für die notwen- 
dige Genehmigung und überträgt die weitere Verantwortlichkeit an private Entwickler. Mit diesem Modell wird zwar die städtebauliche Erneuerung und Entwicklung vorangetrieben, allerdings werden Staatsvermögen und daraus erzielte Gewinne privatisiert. Für das Beispiel Tirana wird - und das gilt mit einer gewissen Berechtigung für die gesamte ex-sozialistische Periode - eine sehr spezielle Spielart von Urbanismus konstatiert, die sich mit gängigen vergleichenden Theoriemustern nicht hinreichend erklären lässt. Wir haben für die vorliegende Studie deshalb eine relationale Perspektive gewählt, um dem evolutionären Moment des spezifischen Kontextes Albaniens Rechnung zu tragen. Wir lehnen uns an das Konzept der ,ordinary city “ an und diskutieren in diesem Zusammenhang letztlich auch die Reichweite von Sozialismus und Post-Sozialismus als erklärende Konzepte.

Schlagwörter: Stadtwachstum, Urbanisierung, Städtebauliche Großprojekte, Transformation, post-sozialistischer Urbanismus, Albanien, Tirana.

Gjithçka mund të ndodhë, jetojmë në Tironë [Anything can happen, we live in Tirana $]^{1)}$

\section{Introduction}

Tirana was founded at the beginning of the $17^{\text {th }}$ century, which is relatively late in SouthEast Europe. At the beginning of the $20^{\text {th }}$ century, the later capital was still a small Ottoman country town. The irregular street plan, unpaved roads, small-scale parcelling and the predominance of one- or two-storey residential buildings were the striking characteristics. At best, prominent religious or secular functional buildings such as the minaret of the Et'hem Bey Mosque or the clock tower flanking the central bazaar area covered the silhouette without dominating the cityscape.

In principle, urbanity first came to Tirana when it became Albania's capital in 1920. The planned expansion to the south under Italian influences and its regular pattern soon indicated the clear break with older urban structures. In other South-East European countries such processes took place as early as the $19^{\text {th }}$ century (GöLER and LEHMEIER 2011). In fact, urbanisation in Tirana is closely linked to the socialist era. Since that period of time, the functional primacy of the city has intensified and has also been demographically underpinned. Without any doubt, Greater Tirana can be called a primate city today (DOKA and GöLER 2008). This is in particular an expression of strong growth dynamics in the transition period: Prior to that, in socialist times, migration was highly controlled and labour force was, due to agriculture and mining activities, sent to rural and mountainous areas. From the mid-1990s at the latest, the population pressure there resulted in massive migratory movements from the periphery to the centre. This was a

\footnotetext{
1) A phrase from the rap song "Tirona", performed by "West Side Family" in 2004 (https://www.youtube.com/ watch? $v=Q P k t v c c n 1 s 0$, last accessed April 24, 2020).
} 
consequence of the destabilisation of living conditions in the countryside. In this context, the migration and settlement system in Albania made the transition from a stage of underurbanisation of the socialist times (SJÖBERG 1992) to hyperurbanisation at an accelerated pace (GöLER 2017).

This mass migration is, besides de-industrialisation and tertiarisation, perhaps the most striking element of the early post-socialist period in Albania. When analysing the subsequent development dynamics, it must be taken into account that the country's capabilities for entering a sustainable transition process were very limited. With regard to urban space, three phases can be clearly distinguished.

The phase of kioskisation (BECKER and GöLER 2000) or "Kioskism", respectively (Mele and Jonas 2020, p. 232) is symbolised in particular by spontaneous, informal trends in urban development. A special element was the mushrooming of small-scale forms of retail trade in the turbulent 1990s (PoJANI 2011). The kiosk phenomenon can be seen as a consequence of the introduction of market forces. In general, it is an integral part of the subsequent socio-spatial reordering of post-socialist urban spaces (AxENOV et al. 1997). The main drivers - such as decades of living in a shortage economy, the lack of private business, and high unemployment - may be comparable to similar processes in other transition countries, but the dynamic of kioskisation in Tirana is outstanding.

This chaotic phase was followed by political stabilisation and economic consolidation during the 2000s. Albania, like most of the transition countries, had found its way out of the first transition crisis (GöLER 2006). Growth rates that were well above the average of most East- and South-East-European countries led to significant improvement of living conditions, substantial increase in wealth, and the formation of a middle class.

Similarly, the last decade can be called a phase of formalisation, if we take the progress in informal settlements with cadastral registration and infrastructural development measures into account (MELE and JoNAS 2020). Other indicators are the introduction of street names, the prevention, dismantling or systematic demolition of illegal buildings, and the monetisation of electricity and water supplies. The pending EU accession may be seen as the missing piece of the puzzle in this regard.

Even if the trend of small-scale inner-city densification as well as urban sprawl is still continuing, with large urban developments (LUD) there is currently an unprecedented quality and dimension of urban transition arising in Tirana (Figure 1). There is the multiple redesign of Skanderbeg Square, the continuation of the main axis from socialist times replacing the former railway station or the new mosque as Albania's largest place of worship, just to name a few of the projects already completed. Additionally, there are a number of condominiums on the outskirts of the city centre, i.e., integrated, large-scale residential complexes with up to 30 or more apartment buildings, and the countless gated communities in the suburban fringe. Completely new players in the game are high-rise buildings with 20 to 30 floors and more than 80 meters in height. Alone, ten of these tow$\mathrm{ers}^{2)}$ have been planned or are already under construction in the proper city centre around Skanderbeg Square or within a short walking distance (Figure 2).

\footnotetext{
2) Albanians call these buildings "Kulla", which literally means "tower". In the traditional sense, Kullas are fortified residential buildings from the Ottoman period, which are typical in Northern Albania.
} 


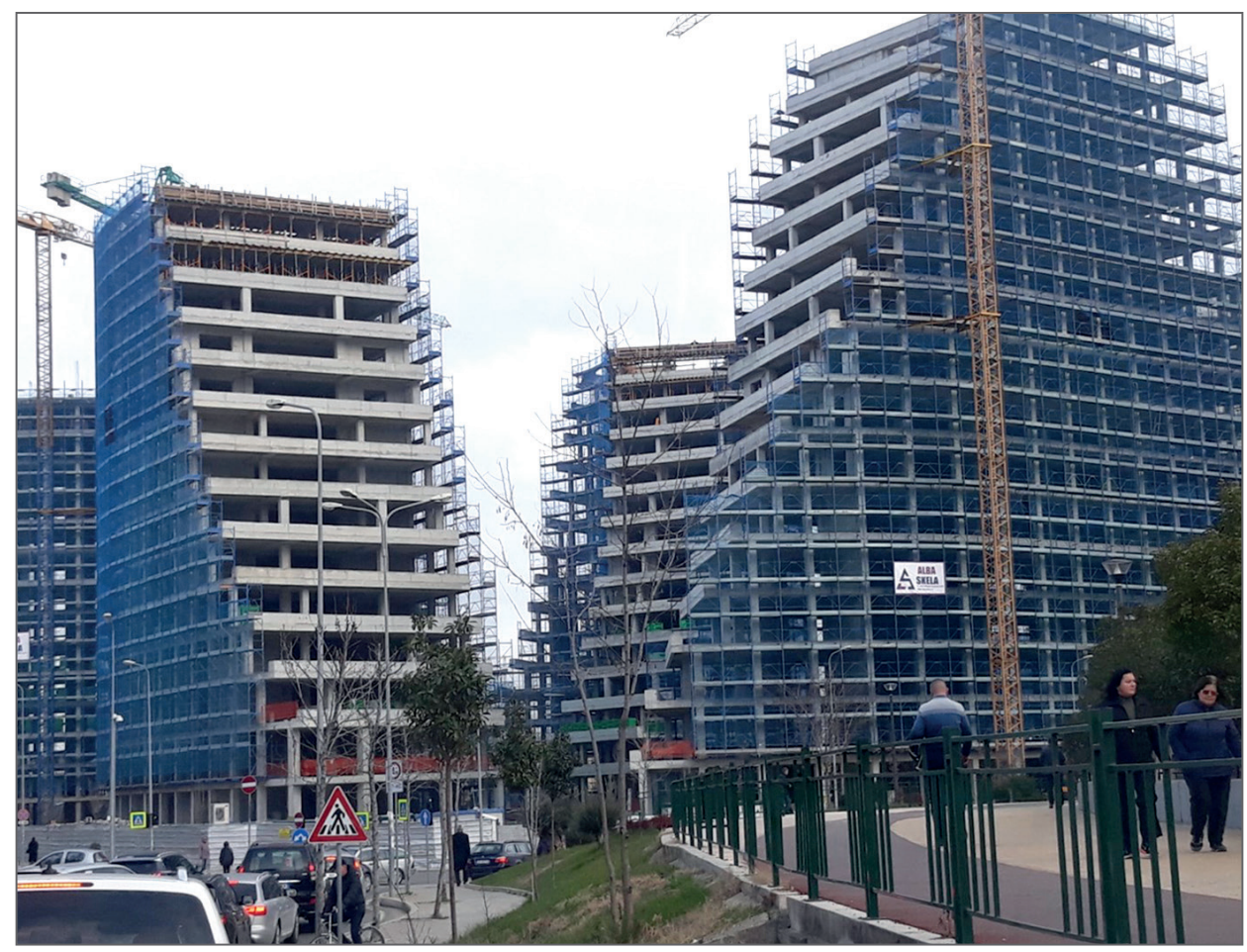

Source: Photo by Dhimitër DokA, Feb. 18, 2020

Figure 1: The mega-project "Magnet" ("Lake View Residence”). Construction sites of this size are new in Tirana

The underlying concept of a post-modernist urban redevelopment according to international standards goes back to the so-called "French Plan", i.e., a masterplan initiated by the well-known former mayor of Tirana and designed by a French bureau in 2003. After the change of government, the plans were considered closed. It was not until 2013, when the former mayor became Prime Minister, that the concept was brought out again and resumed with the redesign of the Skanderbeg Square in the period from 2015 to 2017. At the same time, building permits were issued for a number of high-rises in the direct vicinity of the square (NiENTIED and Aliaj 2018, p. 210ff). In terms of scale and organisational background, these objects undoubtedly represent a completely new phenomenon of urban dynamics, not that much in the Balkans but in Tirana/Albania. There, smallness, fragmentation and informality have dominated so far. Recently, the field of urban development has opened to control by large and powerful private players (POJANI and MACI 2015, p. 271). In this respect, we scrutinise the latest urban trajectories in Tirana with a special focus on LUDs. This kind of "vertical urbanism" (HARRIS 2015) is, in the context described in this section, interpreted as another aspect of formalisation on the way towards becoming a capitalist urban fabric. 


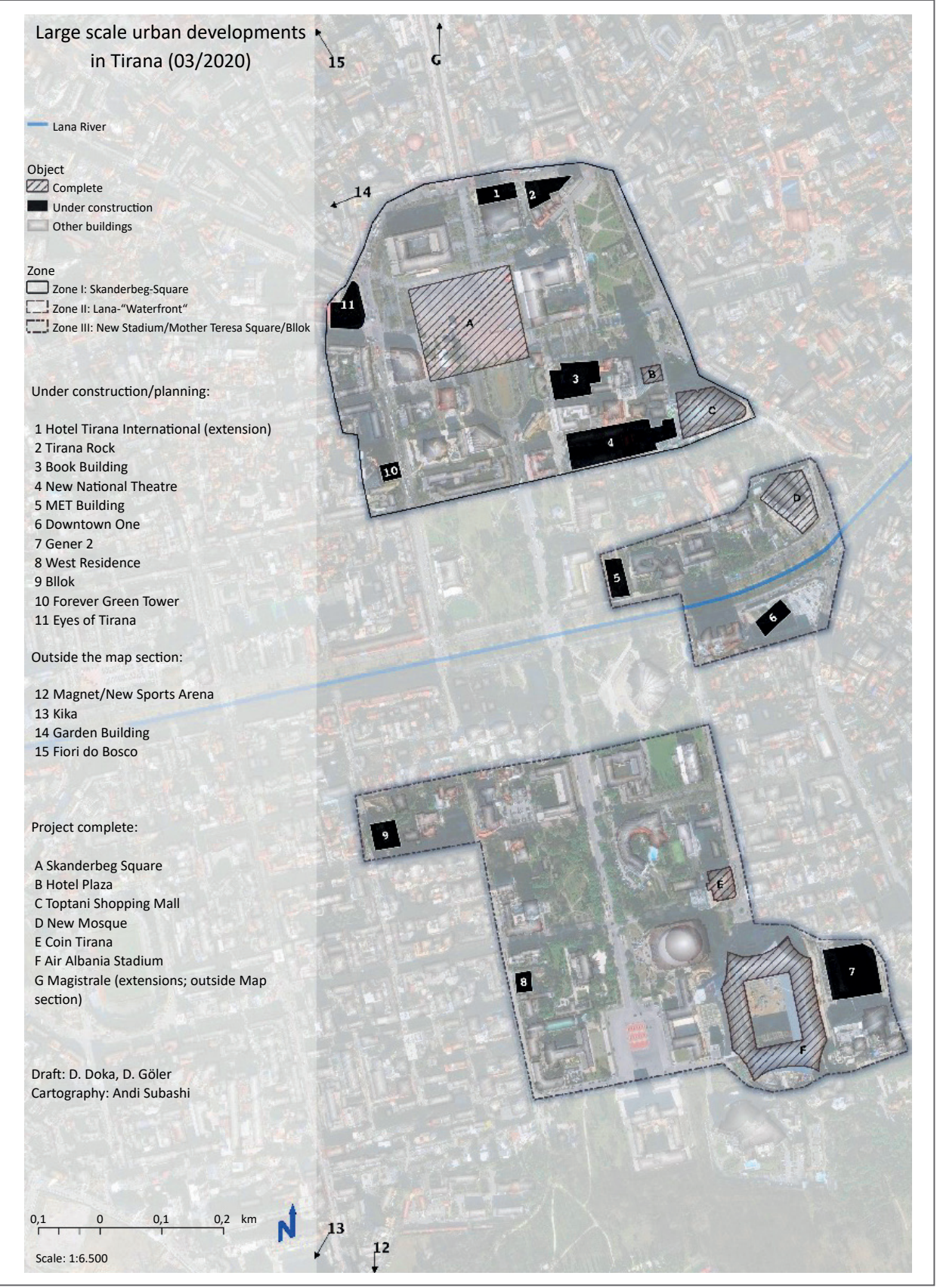

Source: Draft: Dhimitër DoKA, Daniel GöLER (March 2020); Cartography: Andi SubaSHI

Figure 2: Areas with large-scale urban developments and high-rise buildings in Tirana 


\section{Research questions and methodology}

As large and visible as the high-rise Kullas in Tirana are, very little is known about their general background, genesis and investors. The same is true for planning and approval procedures in detail. In this respect, the first concern of this contribution is to shed some light on such somehow surreptitious developments. We investigate the hard facts of Tirana's "stealth urbanism" (MURRAY 2017, p. 42). The empirical basis for discussion was gained at first through field observation and an analysis of available documents. In a second step, our findings were mirrored by expert opinions, which were collected through in-depth interviews with four distinguished representatives from public authorities and science. ${ }^{3)}$ In addition, media reports provided interesting insights into the accompanying public discourses.

First of all, a number of research questions have emerged which need to be asked: Who are the key players behind the processes and decisions? To what extent does transnational integration into global urbanism take effect? Or will we find indications of re-nationalisation in the sense of ,Albatross Investments“", ${ }^{4}$ i.e., the trend towards slight internationalisation with full control by national or diasporic actors occurring simultaneously? This leads to the second part of the analysis: Is the current urban redevelopment in Tirana and this manner of "anchoring financial capital in the city" (THEURILLAT et al. 2016, p. 1510) a sign that global phenomena are now becoming prevalent in Albania, too? This cannot be taken for granted and has to be discussed, not least when considering the underestimated role of "locally specific structures of opportunities" (HALBERT and ATTUYER 2016, p. 1353) that influence the financialisation of urban production as well. Consequently, we have to analyse the variations in Albanian uniqueness at the same time, with its own scales, patterns, dependencies, and history. Thus, the evolutionary character of post-socialist urbanism (which will be elaborated on as the study's guiding concept in the next section) comes into play.

At this point, we have to refer to the ongoing debates on the post-socialist city by FerenČuhoví and Gentile (2016), Hirt et al. (2016), TuviKene (2016) or Müller (2019), as they raise the question of the scope of socialism and post-socialism as explanatory concepts. How far serves post-socialism still as a relevant analytic category in the context of urban geography and comparative urbanism, a concept of thinking "the urban through the diversity of urban experiences" (RoBINSON 2016, p. 189)? In order to anticipate the answer at this point of the discussion, we agree with CHELCEA and DRUŢĂ (2016, p. 537) and "think that it sometimes does, but sometimes does not" with regard to renewed theoretical reflections along post-colonial critique that has "the potential to think with the

\footnotetext{
3) Interviews cover expertise from both public authorities - (E I) National Territorial Planning Agency, specialist for spatial planning and urban development; (E II) INSTAT Albania, specialist for GIS-Systems in the Department of Cartography and Statistics - and theorists - (E III) Lecturer in architecture and urban development at the Technical University of Tirana, former advisor of the Prime Minister on spatial development issues; (E IV) Lecturer in the Department of Archeology and Heritage at the State University of Tirana, holds a PhD in architecture. Expert's voices are referenced with E I - E IV.

4) We hereby refer to the term "albatross tourism" created by Derek HALL (2017, p. 324), which in another context emphasises the ethnic, diasporic component of the phenomenon (in this case, tourism).
} 
diversity of urban outcomes" (RoBINSON 2016, p. 189) by preferring "variation-finding studies" (loc. cit, p. 191).

By focusing on the context of Tirana, this leads consequently to the still exciting question of whether we can still treat findings on ex-socialist cities as "anomalies" (FERENČUHOví and GENTILE 2016, p. 492), simply because we focus on singularities, exceptional phenomena or laboratories - hence, the path-dependent "own ways". This is in line with accepting the city per se as "ordinary" (RoBINSON 2006), no matter whether it is a Western, Eastern, socialist or post-socialist one. Referencing the latter, the interpretation of "Post-socialism as a De-terrorialized Concept" (TUVIKENE 2016) may serve as the conceptional key by looking beyond the regional limitation - in our case, Eastern and South-Eastern Europe - while accepting distinct historical contexts.

Taking up this discussion, we stress the institutional field of a dynamic South-Eastern European metropolis. The example of Tirana serves to determine what we expect from ex-socialist, typically neoliberal urban developments. Further on, we analyse how these expectations manifest in its place-specific, unique urban environment. The contribution provides a deeper understanding of Tirana's LUDs and helps to critically assess them in the context of the given space and time. The overarching aim of the study is to identify the main effects and outcomes of metropolitan metamorphosis there as a result of limited internationalisation and to provide another example of modular input for the theory of urbanism in transition contexts.

\section{Conceptual focus on Tirana: Moving towards an evolutionary approach}

In this section we make a proposal where and how we will suitably recognise the preceding reflexions in theories of the urban beyond representing "cases onto themselves" (SJÖBERG 2014, p. 313). Thus, we use a relational perspective and follow the appeal for an "approach to the comparison of cities that recognizes both the territorial and the relational histories and geographies that are behind their production and (re)production" (WARD 2010, p. 480). Without anticipating the answer to the crucial question of dominance of the global vs. prevalence of the local, but with regard to Albania and Tirana, respectively, some specific constellations in the sense of the relational perspective must be taken into account to "emphasize contextual specificity, institutional diversity and the divergence of evolutionary pathways" (BRENNER 2004, p. 18). In the given context, we call this approach an "evolutionary urban transition" and, thus, highlight in the following several specific constellations that make Albania different from other transition countries.

First of all, there is the country's complex path of transition after socialism. Starting from an extremely low level of socio-economic development and stuck in isolation when the communist regime fell in 1991, the country was marked by an unstable path of "interrupted transition" (GöLER 2006). At the same time, a strategy of extreme economic liberalisation, privatisation and individualisation was adopted. The state-owned housing stock was privatised quickly and completely transferred free of charge to the residents (KUÇI 
2016, p. 153). On the one hand, a corresponding capital stock among the residents would not have been available, anyway. On the other hand, there was enormous pressure on the housing market, particularly in the cities of central Albania and much more in the capital. This went back not only to the cramped living conditions of the communist past, but also to the massive immigration from all parts of the country following the end of migration restrictions.

In other cities in transition like Budapest (KIss 2002), brownfields were usually available for urban development projects. Such areas are rare in Tirana. The few examples were rapidly occupied by informal markets (BECKER and GöLER 2000) or squatter settlements (BECKER et al. 2005). The result of the first two decades of transition in Tirana, with all its spontaneity, informality and creativity, then showed rather clear characteristics of urban developments of what is called the Global South, rather than an alignment with, for example, Western patterns (NASE and OCAKÇı 2010). In Eastern European capitals such as, among others, Prague (Temeloví 2007, p. 172), integration into international financial markets and huge international investments initiated a new dynamic of urban renewal in the 1990s. In Tirana, these main drivers for internationalisation are still missing.

With a view to exactly this specific context, POJANI (2011, p. 838) points to a reversal of the urban transition process known from the Central and Eastern European Countries (CEE), where a rapid increase in office space was followed by retail trade and finally by living space: In Albania and Tirana, respectively, the almost explosive expansion of living space was followed by the gradual formalisation of the, as already mentioned, still quite small-scale retail trade. The first "shopping mall" in Albania opened up in Greater Tirana in 2005; the first do-it-yourself store followed in 2009 (GöLER 2010). The "Toptani Center" (see Figure 2), which opened in 2017, then represented the first mall project according to international standards in the inner city.

Due to the country's long-lasting political and economic disintegration, there was very limited demand for office space or high-class hotels. After 1991, the corresponding needs were met by converted living space and/or new mixed-use buildings, preferably in the "Bllok", which was previously the segregated residential area of the socialist nomenklatura (BECKER et al. 2005). In the 2000s, such complexes with cafes, bars and restaurants or retail trade on the ground floors, office space on the middle floors and apartments on the upper ones mushroomed throughout the urban area. The consequences of this trend were densification on the ground floors and the rise of Tirana's skyline. While eight to ten floors were common at the beginning, the Hotel Tirana International (see below), the tallest building in socialist Albania with 15 floors, which was iconic at that time, became the new benchmark.

Astonishingly, the construction boom left out the central area around Skanderbeg Square and the Boulevard, due to the dominance of public buildings there. This is a result of a long-standing "moratorium on construction in the center" (POJANI 2011, p. 839). Construction activity there was indeed limited to maintenance and refurbishment. It is more than symbolic that the only free flank of the central square is now being built on in connection with the spread of a LUD (the "Eyes of Tirana" project; see below). In this respect, the "Post-socialist development gradient of CEE cities" mentioned by NASE and 
OCAKÇı (2010, p. 1842) can be understood in limbo, fluctuating between intrinsically lagging behind and following the dynamics of globalisation.

No matter which urban phenomenon or function is considered, in the case of Tirana the analysis leads sooner or later to the specific. Then the explanation requires the consideration of time, identity, location and context, hence - as mentioned above - the relational perspective. This has nothing to do with a new "Balkanization of Space" (NASE and OCAKÇI 2010, p. 1837 and p. 1858), which is an unhelpful regionalising concept without analytical depth. Strictly speaking, it has only little to do with the question of socialism vs. post-socialism. The crucial factors for the explanation of Tirana's urbanism are practices of urban governance with the background of the collective experience of isolation, asymmetrical power constellations and limited democratic participation. As will be shown by using the evolutionary approach, this is also the case when scrutinising large urban developments (LUDs) in Tirana in detail.

\section{Large urban developments in Tirana}

\subsection{Definition}

Large-scale urban development projects are mostly converted revitalisation areas (industrial wastelands, docklands, waterfronts or similar, e.g., SwyngEDouw et al. 2002) or otherwise defined urban areas. Typically, they are "delinked, both operationally and aesthetically, from the broader sociospatial fabric of the city" (BRENNER 2019, p. 163). Sometimes they include complete neighbourhoods. Usually these are projects in a range of at least two-digit hectare numbers. The most prominent example from the Balkans is undoubtedly the Belgrade Waterfront, an investment of 3.5 billion Euros on around 200 hectares of inner-city space along the Sava River (Jocić 2019, p. 117ff; Aly 2019; MACHAlA and Koelemais 2019; GrubBauer and ČAmprag 2018). Albania and Albania's capital cannot yet compete in such dimensions.

However, fundamental organisational elements seem to be quite comparable: There is the declaration of some of the objects as a public-private partnership (PPP), a lack of integration into the existing superordinate urban planning, a lack of transparency regarding both project development and the authoritarian management, as well as the impression of being somewhat alienated in the given, not to say historical, urban physiognomies. Apart from that, Tirana's LUDs are usually isolated objects that are scattered within the inner-city area, although they have a certain orientation around the central Skanderbeg Square (Figure 2). Neither compact functional city development nor any kind of spatial clustering are recognisable. As a rule, the Kullas have creative names with positive connotations; they contain a functional mix of uses, preferably with commercial ventures, offices and high-quality living space (Table 1). Some of the properties also have leisure, sports or cultural facilities. The architectural language is strongly postmodern, but sometimes also nationalistic. It is not least this functional and physiognomic eclecticism that underlines the evolutionary argument and makes the positioning between global influence and individual path difficult. 


\begin{tabular}{|c|c|c|c|c|c|c|}
\hline Nr. & Project & $\begin{array}{l}\text { Size (space, } \\
\text { floors, height) }\end{array}$ & Function & $\begin{array}{c}\text { Investor and } \\
\text { developer/ar- } \\
\text { chitect }\end{array}$ & $\begin{array}{l}\text { Costs } \\
\text { (in } € \text { ) }\end{array}$ & $\begin{array}{c}\text { Start / } \\
\text { completion }\end{array}$ \\
\hline 1 & $\begin{array}{l}\text { Hotel Tirana } \\
\text { International } \\
\text { (extension) }\end{array}$ & $\begin{array}{l}32,000 \mathrm{~m}^{2} \\
35 \text { floors } \\
133 \mathrm{~m}\end{array}$ & $\begin{array}{l}\text { 5-star hotel, } \\
\text { service }\end{array}$ & $\begin{array}{l}\text { Geci; } \\
\text { Bolles+Wilson }\end{array}$ & - & - \\
\hline 2 & Tirana Rock & $\begin{array}{l}38,000 \mathrm{~m}^{2} \\
25 \text { floors } \\
80 \mathrm{~m}\end{array}$ & $\begin{array}{l}\text { high-class } \\
\text { residences }\end{array}$ & $\begin{array}{l}\text { ANA; } \\
\text { MVRDV }\end{array}$ & 50 mio. & $\begin{array}{l}2020 / \\
\text { under con- } \\
\text { struction }\end{array}$ \\
\hline 3 & Book Building & $\begin{array}{l}40,000 \mathrm{~m}^{2} \\
21 \text { floors } \\
77 \mathrm{~m}\end{array}$ & $\begin{array}{l}\text { mixed use } \\
\text { (commercial, } \\
\text { office, residen- } \\
\text { tial) }\end{array}$ & $\begin{array}{l}\text { Techno-Alb; } \\
\text { Johan Anrys }\end{array}$ & - & $\begin{array}{l}2019 / \\
\text { under con- } \\
\text { struction }\end{array}$ \\
\hline 4 & $\begin{array}{l}\text { New National } \\
\text { Theater }\end{array}$ & $\begin{array}{l}9,200 \mathrm{~m}^{2} \\
\text { (ground) } \\
- \\
-\end{array}$ & $\begin{array}{l}\text { commercial, } \\
\text { culture }\end{array}$ & $\begin{array}{l}- \\
\text { (Bjarke Ingels } \\
\text { Group, with- } \\
\text { drawn) }\end{array}$ & 30 mio. & - \\
\hline 5 & MET Building & $\begin{array}{l}1,800 \mathrm{~m}^{2} \\
15 \text { floors } \\
49 \mathrm{~m}\end{array}$ & $\begin{array}{l}\text { mixed use } \\
\text { (commercial, } \\
\text { office, residen- } \\
\text { tial) }\end{array}$ & $\begin{array}{l}\text { MET Invest; } \\
\text { Mario Cucinella }\end{array}$ & - & $\begin{array}{l}2018 / \\
2023\end{array}$ \\
\hline 6 & $\begin{array}{l}\text { Downtown } \\
\text { One }\end{array}$ & $\begin{array}{l}77,000 \mathrm{~m}^{2} \\
37 \text { floors } \\
140 \mathrm{~m}\end{array}$ & $\begin{array}{l}\text { mixed use } \\
\text { (commercial, } \\
\text { office, high- } \\
\text { class residen- } \\
\text { tial) }\end{array}$ & $\begin{array}{l}\text { Kastrati; } \\
\text { MVRDV }\end{array}$ & 75 mio. & $\begin{array}{l}2019 / \\
2024\end{array}$ \\
\hline 7 & Gener 2 & $\begin{array}{l}- \\
21 \text { floors } \\
-\end{array}$ & $\begin{array}{l}\text { mixed use } \\
\text { (commercial, } \\
\text { office, residen- } \\
\text { tial) }\end{array}$ & Gener 2 & - & $\begin{array}{l}2018 \text { / } \\
\text { under con- } \\
\text { struction }\end{array}$ \\
\hline 8 & $\begin{array}{l}\text { West Resi- } \\
\text { dence }\end{array}$ & $\begin{array}{l}8,869 \mathrm{~m}^{2} \\
13 \text { floors } \\
35 \mathrm{~m}\end{array}$ & $\begin{array}{l}\text { mixed use } \\
\text { (commercial, } \\
\text { gastronomy, } \\
\text { residential) }\end{array}$ & $\begin{array}{l}\text { lnvest Society; } \\
\text { TDT \& Partners; } \\
\text { Stefano Boeri }\end{array}$ & - & $\begin{array}{l}2019 / \\
2024\end{array}$ \\
\hline 9 & Bllok & $\begin{array}{l}- \\
11 \text { floors } \\
30 \mathrm{~m}\end{array}$ & $\begin{array}{l}\text { mixed use } \\
\text { (commercial, } \\
\text { office) }\end{array}$ & $\begin{array}{l}\text { Invest Society; } \\
\text { Stefano Boeri }\end{array}$ & - & $\begin{array}{l}2018 \text { / } \\
\text { under con- } \\
\text { struction }\end{array}$ \\
\hline 10 & $\begin{array}{l}\text { Forever Green } \\
\text { Tower }\end{array}$ & $\begin{array}{l}12,400 \mathrm{~m}^{2} \\
20 \text { floors } \\
85 \mathrm{~m}\end{array}$ & $\begin{array}{l}\text { mixed use } \\
\text { (commercial, } \\
\text { gastronomy, } \\
\text { hotel, office, } \\
\text { residential) }\end{array}$ & $\begin{array}{l}\mathrm{Al}+\mathrm{GI} ; \\
\text { Archea Asso- } \\
\text { ciati }\end{array}$ & 25 mio. & $\begin{array}{l}2009 / \\
\text { under con- } \\
\text { struction }\end{array}$ \\
\hline 11 & Eyes of Tirana & $\begin{array}{l}44,300 \mathrm{~m}^{2} \\
26 \text { floors } \\
85 \mathrm{~m}\end{array}$ & $\begin{array}{l}\text { mixed use } \\
\text { (commercial, } \\
\text { office, hotel, } \\
\text { residential) }\end{array}$ & $\begin{array}{l}\text { Concord } \\
\text { Investment; } \\
\text { Ideal Construc- } \\
\text { tion; Henning } \\
\text { Larsen }\end{array}$ & - & $\begin{array}{l}2018 / \\
\text { under con- } \\
\text { struction }\end{array}$ \\
\hline
\end{tabular}




\begin{tabular}{|c|c|c|c|c|c|c|}
\hline Nr. & Project & $\begin{array}{l}\text { Size (space, } \\
\text { floors, height) }\end{array}$ & Function & $\begin{array}{c}\text { Investor and } \\
\text { developer/ar- } \\
\text { chitect }\end{array}$ & $\begin{array}{l}\text { Costs } \\
\text { (in } €)\end{array}$ & $\begin{array}{c}\text { Start / } \\
\text { completion }\end{array}$ \\
\hline 12 & $\begin{array}{l}\text { Magnet / New } \\
\text { Sports Arena } \\
\text { ("Lake View } \\
\text { Residence") }\end{array}$ & $\overline{-}_{-} 0$ floors & $\begin{array}{l}\text { mixed use } \\
\text { (residential, } \\
\text { office, parking) }\end{array}$ & Gener 2 & - & $\begin{array}{l}2014 \text { / } \\
\text { under con- } \\
\text { struction }\end{array}$ \\
\hline 13 & Kika & $\begin{array}{l}48,000 \mathrm{~m}^{2} \\
- \\
-\end{array}$ & $\begin{array}{l}\text { mixed use } \\
\text { (residential, } \\
\text { office) }\end{array}$ & $\begin{array}{l}\text { KIKA Construc- } \\
\text { tion } \\
-\end{array}$ & - & $\begin{array}{l}2018 / \\
\text { under con- } \\
\text { struction }\end{array}$ \\
\hline 14 & $\begin{array}{l}\text { Garden Build- } \\
\text { ing }\end{array}$ & $\begin{array}{l}42,520 \mathrm{~m}^{2} \\
24 \text { floors } \\
83,5 \mathrm{~m}\end{array}$ & $\begin{array}{l}\text { mixed use } \\
\text { (residential, } \\
\text { commercial, } \\
\text { parking) }\end{array}$ & $\begin{array}{l}\text { Tirana 1; } \\
\text { Archea Asso- } \\
\text { ciati }\end{array}$ & - & $\begin{array}{l}2018 / \\
2022\end{array}$ \\
\hline 15 & Fiori di Bosco & $\begin{array}{l}30,000 \mathrm{~m}^{2} \\
10 \text { floors } \\
-\end{array}$ & $\begin{array}{l}\text { mixed use } \\
\text { (residential, } \\
\text { commercial, } \\
\text { parking) }\end{array}$ & $\begin{array}{l}\text { Concord Invest- } \\
\text { ment, Edil Al; } \\
\text { Oikos Progetti }\end{array}$ & - & $\begin{array}{l}2019 / \\
\text { under con- } \\
\text { struction }\end{array}$ \\
\hline A & $\begin{array}{l}\text { Skanderbeg } \\
\text { Square }\end{array}$ & $\begin{array}{l}40,000 \mathrm{~m}^{2} \\
- \\
-\end{array}$ & $\begin{array}{l}\text { pedestrian } \\
\text { zone, recreation }\end{array}$ & $\begin{array}{l}\text { City of Tirana; } \\
51 \text { N4E }\end{array}$ & 11 mio. & $\begin{array}{l}2015 / \\
2017 \\
\text { (complete) }\end{array}$ \\
\hline B & Hotel Plaza & $\begin{array}{l}46,000 \mathrm{~m}^{2} \\
25 \text { floors } \\
85 \mathrm{~m}\end{array}$ & $\begin{array}{l}\text { 5-star hotel, } \\
\text { business centre }\end{array}$ & $\begin{array}{l}\text { TID; } \\
\text { 51N4E }\end{array}$ & 50 mio. & $\begin{array}{l}2007 / \\
2016 \\
\text { (complete) }\end{array}$ \\
\hline $\mathrm{C}$ & $\begin{array}{l}\text { Toptani Shop- } \\
\text { ping Center }\end{array}$ & $\begin{array}{l}60,000 \mathrm{~m}^{2} \\
12 \text { floors } \\
28 \mathrm{~m}\end{array}$ & $\begin{array}{l}\text { shopping centre } \\
\text { (commercial, } \\
\text { cinema, } \\
\text { food court, } \\
\text { playground, } \\
\text { parking) }\end{array}$ & $\begin{array}{l}\text { EurCol; } \\
\text { MVRDV }\end{array}$ & - & $\begin{array}{l}2010 / \\
2017 \\
\text { (complete) }\end{array}$ \\
\hline $\mathrm{D}$ & New Mosque & $\begin{array}{l}6,000 \mathrm{~m}^{2} \\
-50 \mathrm{~m}\end{array}$ & $\begin{array}{l}\text { mosque, li- } \\
\text { brary, museum }\end{array}$ & $\begin{array}{l}\text { Republic of } \\
\text { Turkey } \\
-\end{array}$ & 40 mio. & $\begin{array}{l}2017 / \\
2020 \\
\text { (complete) }\end{array}$ \\
\hline $\mathrm{E}$ & Coin Tirana & $\begin{array}{l}30,000 \mathrm{~m}^{2} \\
24 \text { floors } \\
83 \mathrm{~m}\end{array}$ & $\begin{array}{l}\text { mixed use } \\
\text { (commercial, } \\
\text { office, residen- } \\
\text { tial) }\end{array}$ & Gener 2 & - & $\begin{array}{l}2004 / \\
2009 \\
\text { (complete) }\end{array}$ \\
\hline $\mathrm{F}$ & $\begin{array}{l}\text { Air Albania } \\
\text { Stadium }\end{array}$ & $\overline{24}$ floors & $\begin{array}{l}\text { multifunctional } \\
\text { (sports, office, } \\
\text { commercial, ho- } \\
\text { tel, residential) }\end{array}$ & $\begin{array}{l}\text { AlbStar, UEFA; } \\
\text { Archea Asso- } \\
\text { ciati }\end{array}$ & 70 mio. & $\begin{array}{l}2016 / 2019 \\
\text { (complete) }\end{array}$ \\
\hline
\end{tabular}

Sources: Agjencia Kombetare e Zhvillimit te Territorit [National Territorial Development Agency] (http://www.azht.gov.al/, last access: Aug. 10, 2020); Bashkia Tirane [Municipality of Tirana]; Keshilli Kombetar i Rregullimit te Territorit [National Council of Territorial Adjustment]; Albanian Construction Portal (https://acp.al/, last access: Aug. 10, 2020)

Table 1: Main characteristics of large urban developments in Tirana (mid 2020) 


\subsection{Indicators}

In the district (Qark) of Tirana, building permits have been granted in clearly increasing numbers in recent years, from 90 (in 2015) to 106 (in 2016) to 231 (in 2017) and 388 (2018; INSTAT 2019, 40); 373 permits are provisionally reported for 2019 . In the period from 2016 to 2018, 30 percent of all building permits granted in Albania and just over 75 percent of the total floor area constructed is in the district of Tirana (INSTAT 2019, p. 41; E II). Beside the increase in numbers, an increase in scales, especially in the city of Tirana, can be observed. The $800,000 \mathrm{~m}^{2}$ floor area approved there represents 60 percent of the country's total (legal) new construction activity. On average, each project covers around $1,630 \mathrm{~m}^{2}$.

Regarding the modal split, three-quarters of the floor space is designated for residential use, and the other one-quarter is planned for other functions such as restaurants, bars, offices or retail. A total of 24 towers with 20 or more floors and over $80 \mathrm{~m}$ height are currently planned. This high number of projects raises questions regarding the consequences for the real estate market. How far will supply and demand fit together, and what are the perspectives? These crucial points will be discussed in the following sections, after the portrayal of five characteristic examples that cover the whole spectrum of vertical urbanism in the city centre and will dominate Tirana's skyline in the near future.

\subsection{Examples}

\section{"Eyes of Tirana"-Availability of urban space}

The already mentioned tower "Eyes of Tirana" is a multi-storey building that is under construction on the site of the former Chamber of Commerce in the very centre of Tirana. It is situated on the Western flank of Skanderbeg Square. This is the only property available around the square. The whole complex includes offices, restaurants, apartments and a hotel covering a total of 26 floors. The project, with a size of approximately $45,000 \mathrm{~m}^{2}$, was originally part of an architecture competition in 2003 (the so-called French plan, as mentioned above), organised by the former mayor, Edi Rama, and won by a Danish company (Henning Larsen). Authorities issued the development permit by the end of 2017, and construction started the following year.

Interestingly, a Spanish consortium is particularly interested in running the integrated 5 -star hotel. It is one of only a few international participants among the examples examined in the study but does not include any direct investment. However, "Eyes of Tirana" may come as an exception in this point.

The main investor is the Albanian Concord Investment Group, founded in 1991. The group has a broad portfolio, including a TV station and one of the oldest, best-known and most active construction companies in the country (Edil Al Sh.p.k., founded in 1994). The company also developed the "European Trade Center" (BECKER et al. 2005, p. 135; see Figure 6) in the 2000s. Furthermore, the group's business is not only focused on develop- 
ment and investment in real estate and shopping malls, but also on telecommunication and energy. The company and its owner family are said to have close and personal relationships with the Socialist Party and thus with both the former and current mayor.

\section{"Hotel Tirana International" - Busted scales}

The close connection between the acting investors and politics is also given in the context of the extension of the Hotel Tirana. The building permit was applied for by the "Atelie 4 Studios", an Albanian company. The prime minister had worked closely with that studio while he was the mayor. The investor also maintains friendly relationships in current government circles. The "Hotel Tirana International" is the modernist component of the architectural ensemble around Skanderbeg Square, embedded between the National Museum and the Opera. It is included in every photo book of Tirana and shown on many postcards. The prominent building with the striking glass facade was without a doubt "Tirana and Albania's landmark during the communist era" (NASE and OCAKÇı 2010, p. 1857).

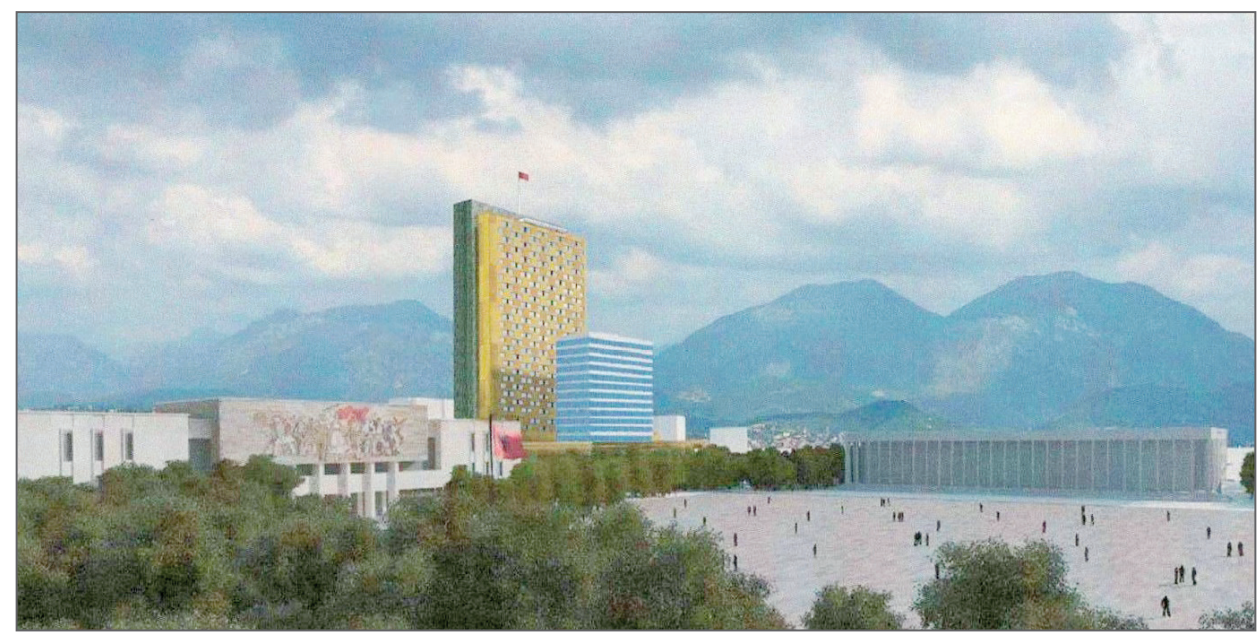

Source: Këshilli Kombëtar i Territorit [National Territorial Council] 2018

Figure 3: Busting the scales - The extension to the Tirana International Hotel is dominating the former landmarks of the communist era

In this respect, it also defined the scale of architecture and urbanism in late socialist Albania, because with its 15 floors, it was actually by far the highest secular, non-industrial building in the country until the end of the 1990s. The Tirana International is now set to be extended by a second complex with approximately 35 floors and $133 \mathrm{~m}$ height. Hotel capacities in the 5-star category are planned as well as further tourist services and other commercial enterprises. An underground, four-level parking garage seems to be a reaction to the extremely limited parking around the site. A look at the plans (Figure 3) shows how 
the given scale and the symbolism associated with Hotel Tirana are deliberately blown up in scale.

\section{The National Theatre - the discourse on politicisation, state power and cultural heritage}

A multi-dimensional discourse has developed around another project in the very centre of Tirana. The focus is on dealing with national heritage, the politicisation of urban development and issues of clientelism and corruption. On a site a few meters southeast of Skanderbeg Square, three related "towers" are to be built on an area of 9,200 $\mathrm{m}^{2}$. The usual mixed use (commercial, office, residential) is also provided here. What makes it a political issue is that the municipality wants to remove the old National Theatre of Albania. This building dates from the 1930s, which is the historical period of detested occupation. Although it covers only a small part of the site, it has to make way for the project and is now being demolished. The new commercial complex on the property was designed by an international architectural company (BIG - Bjarke Ingels Group, which has since withdrawn from the project due to a number of related problems) and will include a new theatre with an open-air stage on the roof (Figure 4); thus, the project will also have a cultural function.

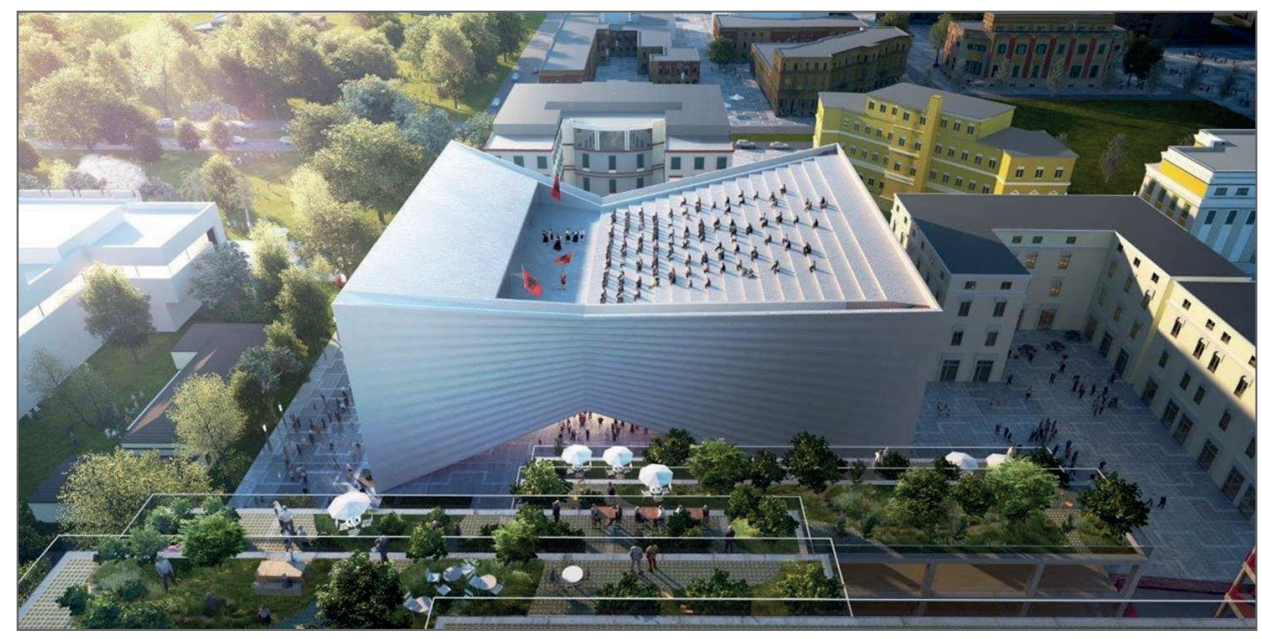

Source: https://www.worldarchitecturenews.com/article/1518384/big-takes-centre-stage-albania, last access: March 26, 2020

Figure 4: Conceptual design of the new National Theater: a multifunctional building with offices, apartments and shops - and a theater

All of this is part of a deal or, to put it in more politically correct terms, a public-private partnership (PPP), in the course of which the main investor, who so far has owned less than $300 \mathrm{~m}^{2}$ of the whole area, will receive most of the land from public authorities while 
in return, the new theatre will be integrated into the project. To this end, a potentially anti-constitutional special law was rapidly adopted in 2018. In fact, the state law bypassed the local parliament. The winner, a real estate and construction company which usually carries out contracts given by public institutions, was already mentioned by name in the tender. Strictly speaking, there was no call for tenders, as the project was an unrequested proposal by the developer.

Protests were apparently unanticipated. Nevertheless, protests by the civil society soon spread. An alliance called "Unë jam Teatri" ("I am the theatre") made up of intellectuals, artists and theatre actors arose and began demonstrating especially against the closure of the previous venue. These protests were triggered by the fear that cultural functions in the neoliberal large-scale project could at best be a marginal part. Broad protests sparked further discussion about the consecutive privatisation of public space and the related expropriation of national ownership in favour of a few elite members of society and government-related actors.

It is not without irony that urban property rights in this area then were quickly transferred to the state level (namely, the Ministry of Cultural Affairs), which ultimately undermined the Tirana City Council. Consequently, the ministry responsible for cultural affairs must now agree to the demolition of a theatre stage that had been used almost without interruption for nearly a century. In view of the massive protests, the contract with the construction company was withdrawn in early 2020, and it was announced that the project would then be implemented exclusively with public funds. So, the protests had an effect in the meantime, but only in the sense of the restitution of the operational forces involved, but not with regard to either new planning or preventing the demolition of the theatre. ${ }^{5)}$

\section{The new Stadium and Arena Centre - the prototype of expropriation}

The prototype of the national expropriation model outlined by using the example of the National Theatre is the new stadium complex that was completed in 2019 (Figure 5). It is located at the southern end of Tirana's main boulevard. In the course of the public-private partnership, the dilapidated sports stadium (the well-known "Qemal Stafa"), which dates from the 1930s, was demolished in 2016 and rebuilt as the "Air Albania Stadium" based on the plans and design of an Italian architectural company.

At the same time, the complex was supplemented by the property developer AlbStar Sh.p.k. with a 112-meter-high tower with 24 floors, which is, as of March 2020, the tallest building in Albania. The main use in addition to the sports facilities is the "Arena Shopping Center", an 80-room hotel and the high-rise office complex. The stadium will host the games of the national football team. This could be the reason why the whole facility is hidden behind a unique set of blinders in red and black, the national colours of Albania.

\footnotetext{
5) NB: It is not without irony and tragedy, that the theatre has been demolished in the meanwhile. Demolition works took place in the early morning of Sunday, May 17, 2020, at the peak of COVID-19-pandemic when curfews were in effect. Not only the authors felt reminded of the times of deepest socialist repression.
} 


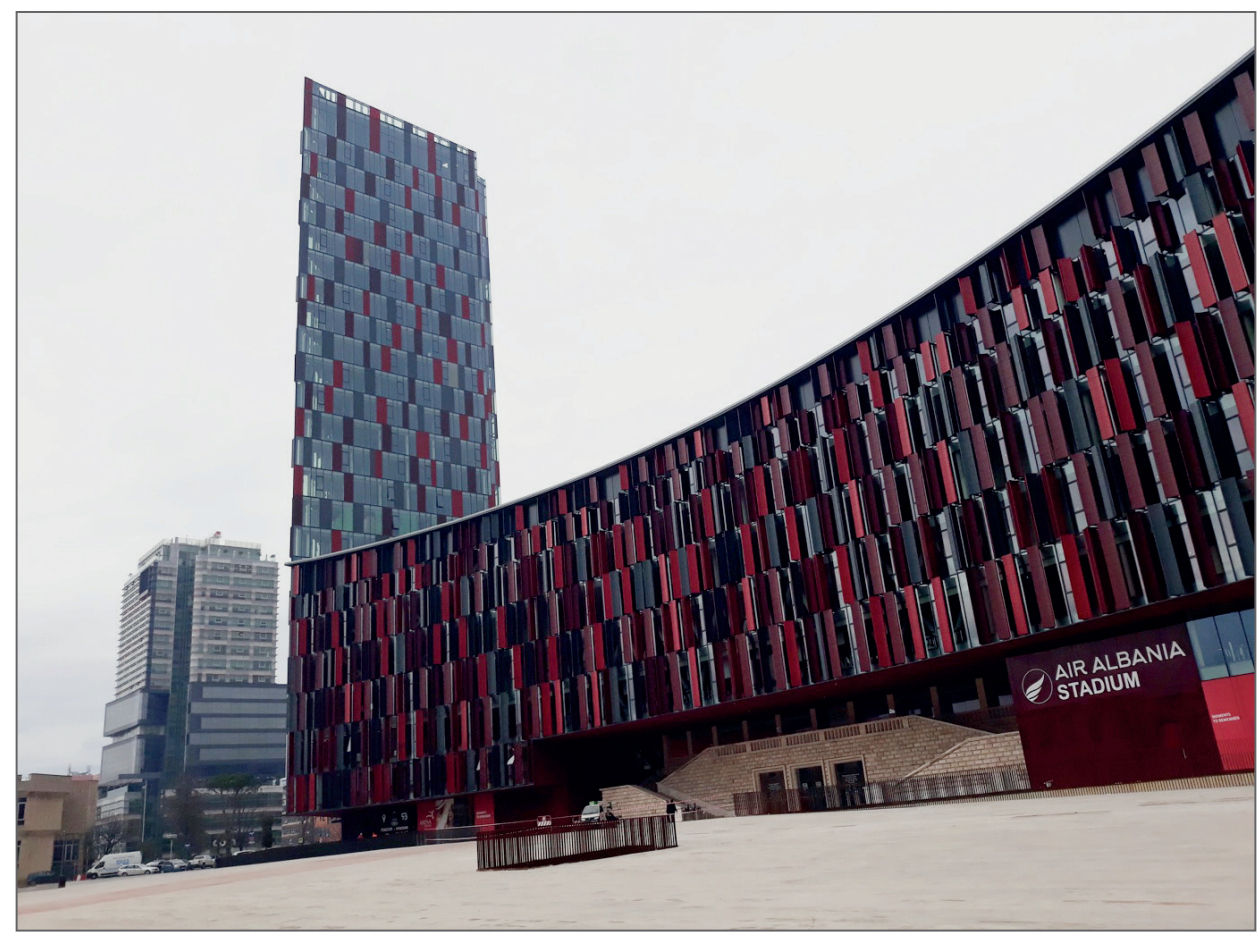

Source: Photo by Dhimitër DoKA, Jan. 30, 2020

Figure 5: The "Air Albania Stadium" and the integrated high-rise office complex. In the background "Coin Albania"

\section{"Downtown One" and the national symbolism}

The reference to national symbolism is not an exception, as the "Downtown One" project, which was called "Downtown Albania" at an initial stage, shows. 2019 was the start of construction works for this ambitious project, a mixed-use skyscraper at a height of $140 \mathrm{~m}$ and with a total surface of $77,000 \mathrm{~m}^{2}$, which will become Albania's tallest building in the near future, overtaking the previous example. The developer is a company named Kastrati Construction. The investors behind this company are two successful entrepreneurs. One is the owner of a myriad of petrol stations in Albania and Kosovo, and the other is a multi-entrepreneur who financed 88 percent of Albania's biggest shopping mall, which is located in the suburban fringe of Tirana (TEG - Tirana East Gate); in his broad portfolio, he includes chrome-mining companies among other activities (GöLER et al. 2015).

The planning has been done by a renowned international architecture consortium with headquarters in Rotterdam, Paris and Shanghai (MVRDV). On their website, the unique position of the project, which should be completed by 2024, is described as follows: "The 
most striking element of the 37-storey tower is its relief of cantilevered houses and offices, which form a pixelated 'map' of Albania, each representing a town or city, turning this building into an icon in the heart of Tirana, Albania." (6) The otherwise less spectacular architecture thus contains very clear national references (Figure 6).

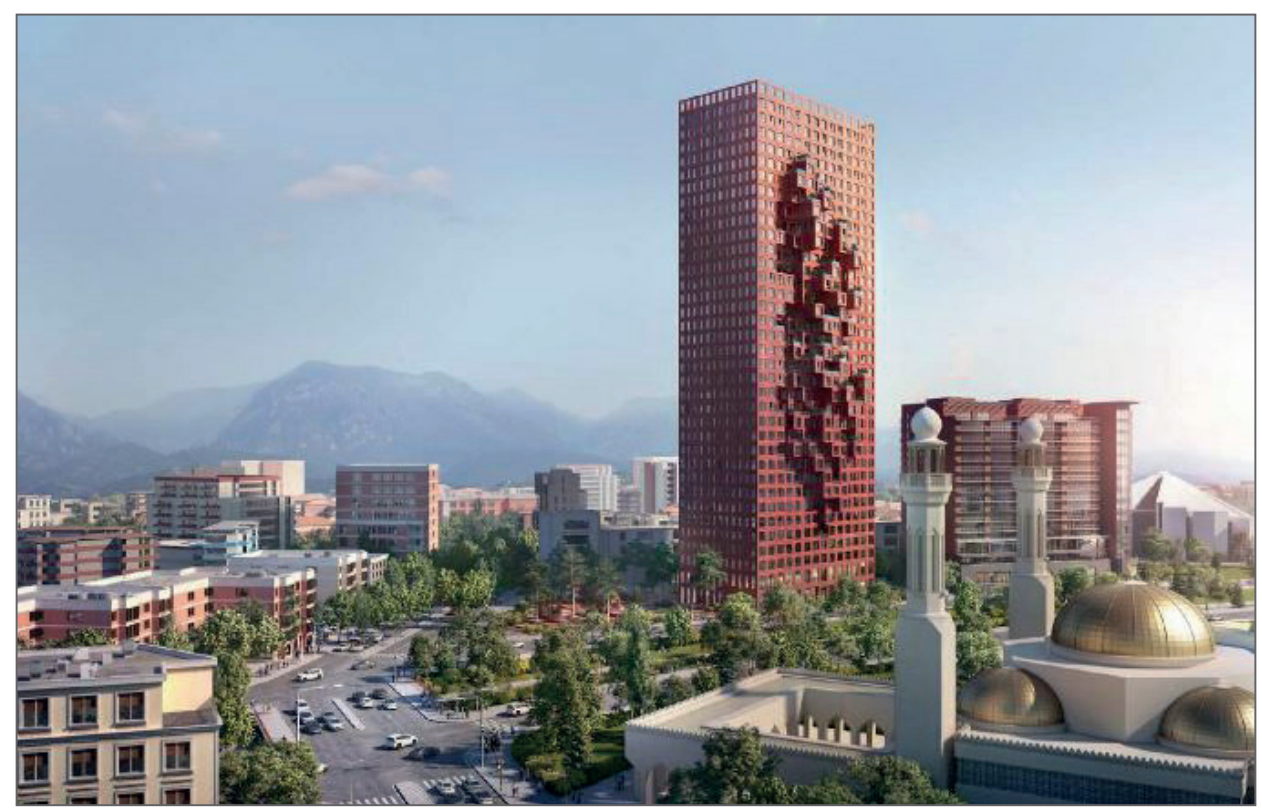

Source: Këshilli Kombëtar i Territorit [National Territorial Council] 2017

Figure 6: The "Downtown One" project. The facade shows a pixelated map of Albania. In the foreground, the new mosque; to the right, the "European Trade Center" from 2005; on the left, the 5-storey scale of the communist period

The fact that public space in the inner city of Tirana that was communal property has been rededicated for this project - privatised, in the sense mentioned above - seems to be of little concern to the actors involved. Interestingly, there was a much-frequented amusement park for children on the site called "7 xhuxhat" [seven dwarfs]. The park was opened with a ceremonial event in mid-2001 by the then (socialist) mayor and today's prime minister. At the time, this opening was celebrated as a symbol of regaining state control over Tirana's public space that had been illegally occupied by kiosks during the 1990s (BECKER and GöLER 2000; PoJANi 2011). It is a paradoxical that the same elite who gave something back to the ordinary people by pulling down a couple of informal buildings almost 20 years ago are now unreservedly sacrificing the interests of capital as part of neoliberal governance.

6) Source: https://www.mvrdv.nl/projects/388/downtown-one-tirana, last access: March 3, 2020. 


\subsection{Large urban developments (LUDs) and the real estate market}

It is noteworthy that the properties are based less on existing demand on the housing and real estate market than that they are initiated and controlled by the investors; this is very evident in the case of the new theatre building. Such an inverted relation is similar, for example, to the case of Belgrade Waterfront (see ALY 2019, p. 34). Pressure on the real estate market that could provide an explanation for the developments in such a quantity and quality and would serve as a kind of justification for the investments in such a dimension is currently not seen, even in the dynamic metropolis of Tirana (E III). The activities are rather in the interest of a relatively small, elite group of investors trying to formalise their capital in connection with speculative objects. So it cannot come as a surprise that there is only little information available about cost structures. In some cases, it is not even clear who the investor is (E II).

Two other mechanisms are, representing the evolutionary perspective, due to the specific set-up of the Albanian financial system, where lending or borrowing money from banks is very expensive and generally unusual. In the case of residential complexes, it is customary to involve the home buyers in the financing before the start of construction activities. Thus, in extreme cases, the construction progress is a kind of pyramid scheme and depends on the deposits. Subsequently, wherever a LUD extends over several plots of private owners, these owners will get compensation from the investor in the form of living or office space in the complex, which is built on their and the neighbours' plots, as it will be the case, for example, in the "Tirana's Rock" project. This strongly resembles the "antiparochi" system which was common in Greece mainly from the 1920s to 1970s in more or less similar conditions (weak state, lack of financial capital, movement to the cities and consequent housing shortage there; Vitopoulou and YiANNAKOU 2020, p. 262). It is obvious that antiparochi, which is still practised in Greece, served as the template for this informal practice on the Albanian housing market.

Nevertheless, the entire process has highly speculative and financially risky features. In many similar projects during the phase of socio-economic consolidation during the 2000s, massive problems appeared soon after completion. In one of the major projects at that time, the "Torre Drin", for example, these problems mainly affected the commercial and office space on the lower floors which had been mostly empty for a long period of time and less so the residential parts. It cannot be because of the location rather in the general demand, because Torre Drin is spatially embedded between the current LUDs of Generation 2.0 such as Plaza, Toptani, Book Building or the new theatre.

The population growth of Tirana is currently between 3 and 4 percent annually, in contrast to 6 to 7 percent in the 2000s. Statistically, approximately 600,000 inhabitants currently have 18 million $\mathrm{m}^{2}$ living space. If the city grows again by up to 200,000 inhabitants in the next 15 years, according to an expert's voice (E III), there would be the need for up to 6 million $\mathrm{m}^{2}$ new living space. The prices are still high, and the 8 percent tax for infrastructural investments recently introduced by the city has made the situation even worse. Until recently, the price per square meter outside Tirana's ring road was between EUR 380 and EUR 500; however, today's prices run from EUR 750 to EUR 950. Based on this, a household with four members would need anywhere from EUR 60,000 to 70,000 to buy an apartment. In the city centre and in the new towers, the prices are 
around EUR 2,500 per $\mathrm{m}^{2}$ of living space and between EUR 8,000 and 10,000 per $\mathrm{m}^{2}$ for offices or retail stores. An apartment of $100 \mathrm{~m}^{2}$ would therefore cost around EUR 250,000, which is no longer affordable for most families and is in no relation to the cost of living or the average income in Albania. If the income ratios are taken into account, Tirana is one of the world's most expensive cities, at least in terms of new properties in the inner city.

\section{Discussion and problematisation}

Large urban developments (LUDs) have not only received negative assessments in the media, but also in the scientific review (ALY 2019, p. 11). It is criticised that the dominance of financial capital in neoliberal urbanism almost automatically leads to a loss of identity, social inequality and exclusion. Principally positive aspects such as the contribution to the global visibility of a metropolis (GOLUBCHIKOV 2010) or to the satisfaction of needs of the local population are less frequently addressed (in BoRnSTEIN 2010; similar to AMBROSE 1991, p. 100, or Temeloví 2007, p. 179). In this respect, an objective analysis, kept as a critical assessment at the same time, seems to be necessary, especially in the case of Tirana. The following section wraps up the findings and will focus on the three aspects: planning, asymmetries and urbanism.

\subsection{The planning system: Bypassing local governance}

LUDs in general and the Kullas in Tirana in particular have not been integrated into the urban planning system (E II), although they will significantly influence the future cityscape and will dominate the fragmented new skyline. The towers come as detached monoliths and appear somewhat alienated from the urban fabric (ALY 2019, p. 11). The national planning system in Albania explicitly states that "objects of national importance or strategic investments for the interests of the country" are not negotiated at the local, but rather at the ministerial level (Ligj 107/2014, article 9; E I). The coordination of the projects is transferred to the national level. One could go so far to say that the National Territorial Planning Agency serves to bypass local governance. In addition to the stamps and signatures of the technical (municipal) authorities, the documents with the building permits of the towers bear the approval of the responsible (national) ministries (e.g., infrastructure and energy, sports, etc.) and the Prime Minister. State authorities and especially private investors are the leading actors (ALY 2019, 11).

All in all, we observe the shift from city government to property-led urban governance. This swap in responsibilities became most evident in connection with the National Theatre, one of the examples in the study. This kind of "privatized planning" (MurRAY 2017 , p. 52) is an outcome of neoliberal urbanism, as it is the case in many other European countries such as UK since the 1970s at the latest (JONES and WARD 2012).

In their study of 13 (Western) European cities, SwYNGEDOUW et al. (2002) refer several times explicitly to the importance of (informal) networks with participants from local and national politics and investors with great power and agency. They assume that the 
elitist and selective character of the network is an essential driver of such investments (loc. cit., p. 573). The findings from our examples underline this very clearly in the case of Tirana, where a few big companies are responsible for a couple of projects. More and more companies are formed solely with the aim to develop a single LUP. All investors and developers maintain more or less openly close relations to decisive public institutions, to government circles and to the leading political party. In one of the most recent cases, the investor is even a member of the national parliament.

\subsection{Asymmetries of power and responsibility}

LUDs are usually constructed as public-private partnerships (PPP), i.e., joint arrangements of public administration and real estate developers (MURRAY 2017, p. 55). This is also the case in Tirana. The state feeds a plot of land or other real estate property into the model and receives in return a public facility integrated into the project, as it is the case with the theatre, stadium or sports park in its purest form. The state is responsible for the approval process. Subsequently, the lead is largely transferred to the private developer. The investor determines planning, construction and maintenance of the project and, above all, guarantees the necessary funding.

The investment for the integrated public institution is amortised through the marketing of the property's main functions such as residential, commercial or office space in an attractive location. Critics actually see an illegal construct behind such a transfer of public goods to (government-related) private hands and even assume that they are "robbery" (MAURER and ISENBERG 2018). Any attempts to clarify this question precisely are currently unsuccessful, as the Albanian constitutional court is still only able to act to a limited extent due to a lack of judges (which is a consequence of the successful implementation of a judicial reform).

However, with regard to questions of governance, power and profit regarding Albania's PPPs, there are definitely clear asymmetries to the disadvantage of the public sector. AMBROSE (1991, p. 92) already described in a similar context the term privatisation generally as an inexact concept. In a transparent "Housing Provision Chain" (loc. cit., p. 94) there is a clear distinction between the "public (democratic accountable)" and "private (non-democratic accountable)" sector. Problems occur at the latest when both development strands are interlinked. In our case studies, the already thin line between public and private is no longer discernible. This means at the same time that the entrepreneurial (private) risk of the investment is at least partially transferred to the public sector. At the same time there is a corresponding lack of control options available during project implementation. This constellation is a very central part of the asymmetry.

\subsection{Urbanism - of exception?}

The utility of traveling theories, i.e., the use of well-known concepts, models or theories mainly from the fields of economics and finance, is limited in the case of Tirana. Since 
the end of socialism, Albania has become more liberal in economic terms than any other country in the context of transition. A capital market, however, is only rudimentary. For example, taking out mortgages from banks is completely unusual. Investments usually have to be made in advance. There is hardly any integration into international financial markets, which is one reason why the country was only affected to a small degree by the subprime crisis after 2008.

There was no international investor involved in a leading role in any of the Kulla projects in our study. As far as it can be seen, the private investments were previously generated in Albania. Thus, we talk about re-invested profits from Albanian business activities. Another indicator of exceptionalism is that the key actors are without exception Albanians. The only international elements are architecture firms, but they are contractors of the Albanian developers. This constellation confirms the "Albatross" thesis formulated in the research outline at the beginning and may also explain the risk acceptance as it has already been recognised by the research team in connection with entrepreneurship in South East Europe (GöLER 2007): The investors know the specifics of the market very well. They are familiar with the whole business environment and are aware of their networks. Last but not least, this constellation enables them to exclude international or, respectively, external influences and competition.

Nevertheless, the entrepreneurial risk is generally high in large-scale speculative projects (FAINSTEIN 2008). This applies even more in Tirana, where the number of projects is large and the demand for upper-class living space and for offices is generally limited (E II; E III). In the given case, the crash of one of the projects would involve the loss of capital, but not necessarily cause private over-indebtedness or business insolvency.

\section{Conclusion}

Findings of the study clearly show the presence of recurring, identical key actors in Tirana's urban development. These originate from the national context. The same is, as far as information on that issue is available, true in the case of the capital invested. The degree of internationalisation in the sense of integration in European or global financial markets is low. Generally, decision-making on the national level prevails. In this regard, knowledge of the rules of the game and access to relevant networks in Albania are essential and explain the dominance of national stakeholders. A convergence with trends in global urbanism can be assumed especially when taking the scales of urban development and the neoliberal agency of governance into account. The goal-oriented adjustment of legal rules and as a consequence the formation of massive asymmetries are central elements of this interpretation of urban governance.

In the Albanian case, the creativity of the mechanisms of expropriation and the intensity of the neoliberal logics of capitalist exploitation may come as an exception. With a relational perspective, which takes specific contexts such as the unique path of transition into account, it may not. Explicitly emphasising the evolutionary moments in the field of "urbanism of exception" may then provide more suitable explanations. 
With regard to current urbanism merely two elements in our study could be claimed as "post-socialist": Weak local institutions and strong national investors. When both come into interaction, expanded scales of the urban are to be expected. In this respect, Tirana's LUDs indicate that investor-driven urban developments have reached Albania's capital and will rapidly contribute to the formation of a new skyline.

\section{References}

Aly H. (2019): Bringing the Political to the City: Politicising vs. Depoliticising Urban Transformation in Belgrade and Tirana. Unpublished Master Thesis, Department of Geography and Regional Research, University of Vienna.

Ambrose P. J. (1991): The Housing Provision Chain as a Comparative Analytical Framework. In: Scandinavian Housing and Planning Research, 8 (2), pp. 91-104.

Axenov K. E., Brade I., Papadopoulos A. G. (1997): Restructuring the Kiosk Trade in St. Petersburg: A New Retail Trade Model for the Post-Soviet Period. In: GeoJournal, 42, pp. 419-432.

BeCKer H., GöLER D. (2000): Stadtstruktureller Wandel in Albanien. Der Transformationsprozeß im konsumorientierten Dienstleistungssektor Tiranas [Urban changes in Albania. The transition process in the consumer-oriented service sector of Tirana]. In: Europa Regional, 8 (1), pp. $2-21$.

BeCKer H., Friemer M., GöLER D. (2005): Aktuelle stadtgeographische Veränderungsprozesse in Südosteuropa - Wohnungsmarkt und Citybildung in Tirana [Current urban change in Southeast Europe - Housing market and the rise of a CBD]. In: Mitteilungen der Fränkischen Geographischen Gesellschaft, 52, pp. 129-156.

Bornstein L. (2010): Mega-Projects, City-Building and Community Benefits. In: City, Culture and Society, 1 (4), pp. 199-206.

BrenNer N. (2004): New State Spaces: Urban Governance and the Rescaling of Statehood. Oxford: Oxford University Press.

Brenner N. (2019): New Urban Spaces. Urban Theory and the Scale Question. New York: Oxford University Press.

Chelcea L., Druță O. (2016): Zombie Socialism and the Rise of Neoliberalism in Post-socialist Central and Eastern Europe. In: Eurasian Geography and Economics, 57 (4-5), pp. 521-544.

DoKA D., GöLER D. (2008): Tirana's Weg ins 21. Jahrhundert - Vom Latecomer der Urbanisierung zum Newcomer im Postkommunismus [Tirana's way into the $21^{\text {st }}$ century - From a latecomer in times of urbanisation to a newcomer in post-communism]. In: Südosteuropa-Mitteilungen, 48 (5-6), pp. 56-67.

Drummond L., Young D. (2020): Socialist and Post-Socialist Urbanisms. In: Drummond L., Young, D. (eds.): Socialist and Post-Socialist Urbanisms: Critical Reflections from a Global Perspective. Toronto: University of Toronto Press, pp. 3-24.

FAINSTEIN S. S. (2008): Mega-Projects in New York, London and Amsterdam. In: International Journal of Urban and Regional Research, 32 (4), pp. 768-785.

Ferenčuhová S., Gentile M. (2016): Introduction: Postsocialist Cities and Urban Theory. In: Eurasian Geography and Economics, 57 (4-5), pp. 483-496.

GöLER D. (2006): Interrupted Transition and Urban Development in Albania. The Case of Tirana. In: Henkel R. (ed.): South Eastern European Countries on their Way to Europe - Geographical Aspects. Leipzig: Leibniz-Institut für Länderkunde, pp. 125-139 (= Forum IfL, 5). 
GöLER D. (2007): Entrepreneurship im Transformationskontext - Eine Analyse des regionalen Gründungsgeschehens in Südosteuropa (mit Beispielen aus Albanien und Serbien) [Entrepreneurship in the context of transition - An analysis of business start-ups in South-East Europe (with examples from Albania and Serbia)]. In: Europa Regional, 15 (1), pp. 23-37.

GöLER D. (2010): „Werkzeug für Tirana“ - Zur Internationalisierung des Einzelhandels in Albanien [,,Tools for Tirana“ - On the internationalisation in retail trade in Albania]. In: Südosteuropa-Mitteilungen, 50 (2), pp. 74-81.

GöLer D., Lehmeier H. (2011): Balkanmetropolen. Urbane Entwicklungen in Belgrad, Bukarest und Sofia [Balkan metropolises. Urban developments in Belgrade, Bucharest und Sofia]. In: Geographische Rundschau, 63 (4), pp. 34-41.

Göler D., Bickert M., Doka D. (2015): Kromi çan bllokadën. Albanian Chromium Mining Revisited. In: Die Erde. Journal of the Geographical Society of Berlin, 146 (4), pp. 271-288.

GöLER D. (2017): From an Isolated State to a Migration Society - Transnationalism and Multilocality as Social Practise in Contemporary Albania. In: JordAn P. (ed.): 10 Years of EU Enlargement. The Geographical Balance of a Courageous Step. Vienna: Verlag der Österreichischen Akademie der Wissenschaften [Austrian Academy of Sciences Press], pp. 137-158.

Golubchiкov O. (2010): World-city-entrepreneurialism: Globalist Imaginaries, Neoliberal Geographies, and the Production of New St Petersburg. In: Environment and Planning A: Economy and Space, 42, pp. 626-643.

GrubBauer M., ČAmprag N. (2018): Urban Megaprojects, Nation-State Politics and Regulatory Capitalism in Central and Eastern Europe: The Belgrade Waterfront Project. In: Urban Studies, 56 (4), pp. 649-671.

Halbert L., Attuyer K. (2016): Introduction: The Financialisation of Urban Production: Conditions, Mediations and Transformations. In: Urban Studies, 53 (7), pp. 1347-1361.

Hall D. (2017): Tourism and a Geopolitics of Connectivity: The Albanian Nexus. In: HaLl D. (ed.): Tourism and Geopolitics: Issues and Concepts from Central and Eastern Europe. Wallingford: CAB International, pp. 322-334.

HARris A. (2015): Vertical Urbanisms: Opening Up Geographies of the Three-dimensional City. In: Progress in Human Geography, 39 (5), pp. 601-620.

Hirt S., Ferenčuhová S., Tuvikene T. (2016): Conceptual Forum: The "Post-socialist" City. In: Eurasian Geography and Economics, 57 (4-5), pp. 497-520.

INSTAT - Instituti i Statistikave [Institute of Statistics] (2019): Vjetari statistikor rajonal 2019 [Regional statistical yearbook 2019]. Tirana: INSTAT.

Jocić N. (2019): Creative Economy in a Postsocialist Transitional Context: Spatial Distribution of Creative Activities and their Interrelation with Urban Milieus in City Quarters of Belgrade. Bamberg: University of Bamberg Press.

Jones M., WARD K. (2012): Excavating the Logic of British Urban Policy: Neoliberalism as the "Crisis of Crisis-Management". In: Brenner N., Theodore N. (eds.): Spaces of Neoliberalism: Urban Restructuring in North America and Western Europe. Malden/MA: Blackwell Publishers, pp. 126-147.

Këshilli Kombëtar i Territorit [National Territorial Council] (2017): Projekt - Vendim (draft) KKT Dt.14.04.2017 Vendim Nr 6 [KKT - National Territorial Council, decision no. 6 from April 14, 2017]. - http://www.azht.gov.al/al/vendime-kkt/arkiv-2017-kkt/projekt-vendim-draftkkt-dt-14-04-2017-vendim-nr6 (last access: March 24, 2020).

Këshilli Kombëtar i Territorit [National Territorial Council] (2018): Vendim KKT - Dt.02.02.2018 Vendim Nr 15 [KKT - National Territorial Council, decision no. 15 from Feb. 2, 2018]. -http://www.azht.gov.al/al/vendime-kkt/arkiv-2018-kkt/vendim-kkt-dt-02-02-2018-vendim$n r-15$ (last access: Aug. 10, 2020). 
Kiss E. (2002): Restructuring in the Industrial Areas of Budapest in the Period of Transition. In: Urban Studies, 39 (1), pp. 69-84.

Kuçı F. (2016): Urban Planning System in Albania, Need for Strategic Approaches. In: International Journal of Advanced Research in Social Science and Humanities, 5 (7), pp. 149-157.

Ligj 107/2014 (2014): Për planifikim dhe zhvillime e territorit [Law 107/2014: On spatial planning and development]. In: Fletorja zyrtare e Republikës së Shqiperise 137/2014 [Official newsletter of the Republic of Albania]. Tirana. - http://planifikimi.gov.al/index.php? eID=dump File $\& t=f \& f=2316 \&$ token $=3 a 82655107 a 5$ d5ff33b895a38e4790af7ca6fd6f (last access: August 10, 2019).

Machala B., Koelemaij J. (2019): Post-socialist Urban Futures: Decision-making Dynamics Behind Largescale Urban Waterfront Development in Belgrade and Bratislava. In: Urban Planning, 4 (4), pp. 6-17.

MAurer V., Isenberg M. (2018): Allianz zum Schutz des Theaters [Alliance for the protection of the theater]. In: www.nachkritik.de. - https://nachtkritik.de/index.php?option=com_content $\&$ view $=$ article $\& i d=16132$ (last access: March 20, 2020).

Mele M., Jonas A. E. G. (2020): Property Relations and the Politics of the Suburban Living Place in the Post-Communist City: Transition Stories from Tirana, Albania. In: Drummond L., Young D. (eds.): Socialist and Post-Socialist Urbanisms: Critical Reflections from a Global Perspective. Toronto: University of Toronto Press, pp. 227-245.

MüLler M. (2019): Goodbye, Postsocialism! In: Europe-Asia Studies, 71 (4), pp. 533-550.

Murray M. J. (2017): The Urbanism of Exception. The Dynamics of Global City Building in the Twenty-First Century. Cambridge: Cambridge University Press.

NASE I., OCAKÇI M. (2010): Urban Pattern Dichotomy in Tirana: Socio-spatial Impact of Liberalism. In: European Planning Studies, 18 (11), pp. 1837-1861.

Nientied P., Aliaj B. (2018): The Public in Search of Identity: New Symbolism in Urban Spaces. A Study of Central Squares of Balkan Capitals. In: Finka M., JAŠšo M., Husár M. (eds.): The Role of Public Sector in Local Economic and Territorial Development. Innovation in Central, Eastern and South Eastern Europe. Cham: Springer International, pp. 203-237.

PoJANi D. (2011): Urban and Suburban Retail Development in Albania's Capital after Socialism. In: Land Use Policy, 28 (4), pp. 836-845.

Pojani D., Maci G. (2015): The Detriments and Benefits of the Fall of Planning: The Evolution of Public Space in a Balkan Post-socialist Capital. In: Journal of Urban Design, 20 (2), pp. 251-272.

Robinson J. (2006): Ordinary Cities: Between Modernity and Development. London / New York: Routledge.

Robinson J. (2016): Comparative Urbanism: New Geographies and Cultures of Theorizing the Urban. In: International Journal of Urban and Regional Research, 40 (1), pp. 187-199.

SJÖBERG, Ö. (1992): Underurbanization and the Zero Urban Growth Hypothesis: Diverted Migration in Albania. In: Geografiska Annaler, Series B: Human Geography, 74 (1), pp. 3-19.

SJöBERG Ö. (2014): Cases onto Themselves? Theory and Research on Ex-socialist Urban Environments. In: Geografie, Czech Geographical Society, 119 (4), pp. 299-319.

Swyngedouw E., Moulaert F., Rodriguez A. (2002): Neoliberal Urbanization in Europe: LargeScale Urban Development Projects and the New Urban Policy. In: Antipode, 34 (3), pp. $542-577$.

Temeloví J. (2007): Flagship Developments and the Physical Upgrading of the Post-Socialist Inner City: The Golden Angel Project in Prague. In: Geografiska Annaler. Series B, Human Geography, 89 (2), pp. 169-181.

Theurillat T., Vera-Büchel N., Crevoisier O. (2016): Commentary: From Capital Landing to Urban Anchoring: The Negotiated City. In: Urban Studies, 53 (7), p. 1509-1518. 
Tuvikene T. (2016): Strategies for Comparative Urbanism: Post-socialism as a De-territorialized Concept. In: International Journal of Urban and Regional Research, 40 (1), pp. 132-146.

Vitopoulou A., Yiannakou A. (2020): Public Land Policy and Urban Planning in Greece: Diachronic Continuities and Abrupt Reversals in a Context of Crisis. In: European Urban and Regional Studies, 27 (3), pp. 259-275.

WARD K. (2010): Towards a Relational Comparative Approach to the Study of Cities. In: Progress in Human Geography, 34 (4), pp. 471-487. 